\title{
Hepatic Oxidative Stress Induced by Zinc and Opposite Effect of Selenium in Oryctolagus Cuniculus
}

\author{
Rouabhi $\mathbf{R}^{1 *}$, Gasmi $\mathbf{S}^{1}$, Boussekine $\mathbf{S}^{1}$ and Kebieche $\mathbf{M}^{2}$
}

${ }^{1}$ Applied biology department, SESNV Faculty, Larbi Tebessi University, Tebessa, 12000, Algeria

${ }^{2}$ Laboratory of pharmacology and phyotochemestry, University of Jijel, Algeria

\begin{abstract}
The objective of this work is to study the opposite effect of Selenium on the toxicity induced by zinc in rabbits (Oryctolagus cuniculus) Twenty rabbits were given repeated per os (p.o.) administration, five with zinc chloride at $0.24 \mathrm{mg} / \mathrm{Kg} / \mathrm{day}$, five with $0.05 \mu \mathrm{g} / \mathrm{kg} / \mathrm{day}$ of selenium, five with mixture $\left(\mathrm{ZnCl}_{2} / \mathrm{Se}\right) 0.24 \mathrm{mg} / \mathrm{kg}+0.05 \mu \mathrm{g} / \mathrm{kg} / \mathrm{day}$ and five rabbits served as controls. In the present study, Hepatotoxic effect of zinc chloride translated by a decrease of body weight (weight gain), a decreased of lipid rate, an increased in carbohydrate amount and proteins level in the liver. The pro-oxidant effect of zinc chloride on hepatocytes was first investigated. The gavage of $\mathrm{ZnCl}_{2}$ into rabbits at the dose of $0.24 \mathrm{mg} / \mathrm{kg} /$ day, induced stress by a significant reduction of GST, CAT and glutathione peroxidase (GPx) activity, glutathione (GSH) level. In addition, a significant increase in malonedialdehyde (MDA) levels was observed, (index of lipid peroxidation). On the other hand, the supplementation of selenium (Se) $0.05 \mu \mathrm{g} / \mathrm{kg} /$ day orally in rabbits treated with zinc has improved some biochemical parameters and decreased the other harmful effects of zinc; selenium seems to be a simple and effective antioxidant to reduce the imbalance state between the formation of free radicals and antioxidant systems.
\end{abstract}

Keywords: Antioxidant; Oryctolagus cuniculus; Selenium; Zinc chloride; Oxidative stress

\section{Introduction}

Human activities have greatly increased the release of various molecules in the environment that some prove toxic to all living beings. These activities include the food industry, metallurgy, mining, pharmaceutical, power plants, and paper mills. Among the introduced molecules, heavy metals occupied a significant place [1].

The toxic potential of a metal for a living body is based on a myriad of parameters. For the same amount, a metal can be toxic under some conditions and be safe in others. It is therefore essential to understand the ways in which a metal is toxic in order to accurately determine the risk it poses in given conditions [2].

Zinc is both essential for metabolism and detoxification of xenobiotics, but as metal is a pollutant to the environment, in a few doses zinc can cause side effects in human [3-7] and animals [8-14].

The world of biological and medical sciences is invaded by a new concept of "oxidative stress" that is to say, a situation in which the cell cannot control the excessive presence of highly toxic oxygen radicals. Currently, it is well accepted that although oxidative stress is not a disease itself, it is potentially involved in many diseases such as trigger or associated with complications during their evolution.

Over production of free radicals can cause an imbalance in cellular redox status producing oxidative damage to biomolecules, (lipids, proteins, DNA). At the same time, antioxidants, such as glutathione, arginine, citrulline, taurine, creatine, selenium, zinc, vitamin E, vitamin $\mathrm{C}$, vitamin A and polyphenols help to regulate the ROS thus generated. Antiradical is further supported with antioxidant enzymes, superoxide dismutase, catalase, glutathione reductase and glutathione peroxidase those exert synergistic actions in removing free radicals $[15,16]$.

Selenium is a component of glutathione peroxidases, antioxidant enzymes are one of the main defenses against attacks from the body produced by oxygen free radicals, this element is in the environment .It is widespread in earth's crust, most tissues and living cells [17]. This work is an investigation of the opposite role of selenium on the toxic effect of zinc in rabbits (Oryctolagus cuniculus).

\section{Materiel and Methods}

\section{Animals}

Male rabbits strain Oryctolagus cuniculus body weight $1.5-1.9 \mathrm{~kg}$ was used in this study. They have been housed individually in stainless metal cages during an adaptation period of 14 days in a controlled temperature/humidity/photoperiod room $\left(22 \pm 2^{\circ} \mathrm{C} ; 50 \% ; 12 \mathrm{~h}\right.$ dark/ light cycle). The feeding of rabbits was based on specific artificial diet for rabbits, and they accessed water freely.

\section{Treatment protocol}

Rabbits were divided in 4 lots of 5 individuals each: Controls (no treatments), treated with $\mathrm{ZnCl}_{2}$ at $0.24 \mathrm{mg} / \mathrm{kg} / \mathrm{day}$, treated with Se at $0.05 \mu \mathrm{g} / \mathrm{kg} / \mathrm{day}$ and treated with mixture $\mathrm{Zn}+\mathrm{Se}(0.24 \mathrm{mg} / \mathrm{kg} /$ day; 0.05 $\mu \mathrm{g} / \mathrm{kg} /$ day). All treatments are per os (p. o.) way, for 14 days and carried out with conformity to the international guidelines for the care and use of laboratory animals.

\section{Chemicals}

In this study, we used the selenium under sodium selenite $\left(\mathrm{Na}_{2} \mathrm{Se}_{3}\right)$ form, and zinc as zinc chloride $\left(\mathrm{ZnCl}_{2}\right)$, for the treatment of rabbits. All chemicals are provided from Larbi Tebessi university laboratories.

After 14 days of treatment, the rabbits were sacrificed and the organs were picked up, liver and kidney were recovered, weighed and preserved for assays. Some biochemical metabolites (proteins, carbohydrates and fats), and some parameters of oxidative stress in the liver (GSH, GPx, CAT, MDA, GST) was investigated, emphasizing on the role of selenium.

*Corresponding author: Rouabhi R, Applied biology department, SESNV Faculty, Larbi Tebessi University, Tebessa, 12000, Algeria, Tel: 213 213-37-49-03-02; E-mail: r_rouabhi@yahoo.fr

Received April 01, 2015; Accepted April 20, 2015; Published April 26, 2015

Citation: Rouabhi R, Gasmi S, Boussekine S, Kebieche M (2015) Hepatic Oxidative Stress Induced by Zinc and Opposite Effect of Selenium in Oryctolagus Cuniculus . J Environ Anal Toxicol 5: 289. doi:10.4172/2161-0525.1000289

Copyright: (c) 2015 Rouabhi R, et al. This is an open-access article distributed under the terms of the Creative Commons Attribution License, which permits unrestricted use, distribution, and reproduction in any medium, provided the original author and source are credited. 
Citation: Rouabhi R, Gasmi S, Boussekine S, Kebieche M (2015) Hepatic Oxidative Stress Induced by Zinc and Opposite Effect of Selenium in Oryctolagus Cuniculus . J Environ Anal Toxicol 5: 289. doi:10.4172/2161-0525.1000289

Page 2 of 6

\section{Lipids, proteins and carbohydrates estimation protocol}

The determination of total soluble carbohydrates was done in rabbits liver level by the method of [18] at a wavelength of $490 \mathrm{~nm}$. Liver lipids were assayed according to the method of [19], the extraction is as [20]. The method used for the determination of proteins is that of [21] using BSA (Bovine Serum Albumin) as the standard, on the same sample used to assay lipids at wavelength of $595 \mathrm{~nm}$.

\section{Evaluation of GSH, GPx, CAT, GST, MDA}

Glutathione (GSH) level was determined according to the method of [22]. This assay is based on measuring the absorbance of the 2-nitro-5-mercapturic. The latter results from the reduction of the acid 5,5'-dithiobis-2-nitrobenzoic acid (reagent Elleman) by groups (-SH) of glutathione. Once prepared, must undergo homogenate deproteinization (by $0.25 \%$ sulfosalicylic acid) to protect the $\mathrm{SH}$-groups of glutathione.

The enzymatic activity of GPx was measured by the method of [23], using $\mathrm{H}_{2} \mathrm{O}_{2}$ as substrate. The spectrophotometric assay of catalase (CAT) activity was performed according to the method of [24]. The decrease of absorbance is recorded for three minutes by a spectrophotometer at a wavelength of $240 \mathrm{~nm}$ and an extinction coefficient $\varepsilon=39400 \mathrm{~L} . \mu / \mathrm{M} /$ $\mathrm{cm}$.

The activity of glutathione S-transferase (GST) was determined according to the method of [25]. It is based on the conjugation reaction between GST and a substrate, the CDNB (1-Chloro2,4-dinitrobenzene) as a cofactor of glutathione (GST), the conjugation results in the formation of a new molecule: 1-S-glutathionyl 2-4-Di nitrobenzene to measure the activity of GST.

MDA can be detected by a colorimetric reaction with thiobarbituric acid (TBA). Detecting MDA after degradation of polyunsaturated fatty acids 3 or 4 Double peroxidized bonds. This is a highly sensitive method for determining lipid peroxidation in vitro. The assay of MDA is carried out according to the method of [26].

\section{Statistical analysis}

The numerical and graphical results are presented as mean 5 standard error (SE). The significance of the Difference between two treatment groups was verified by the Student's t-test. The degree of statistical significance was set at a level of $p<0.05$. Statistical calculations were carried out using Minitab 16 statistical package and the Excel 13.0 (Microsoft, Inc.).

\section{Results}

\section{Effect of treatments on body weight development}

Our results show a significance increase in body weight in the group treated with zinc/selenium combination, zinc and Se according to the control, contrarily to the group treated with Zn only (Figure 1).

\section{Carbohydrates, lipids, and proteins levels variations}

Hepatic carbohydrates: The treatment by the zinc induces a very high significant decrease $(\mathrm{p}<0.001)$ in the glucose level $(201 \pm 12 \mu \mathrm{g})$ against $(380 \pm 9 \mu \mathrm{g})$ in controls group. However, the selenium has no effect on hepatic glucose level $(395 \pm 10 \mu \mathrm{g})$, and correct the $\mathrm{Zn}$ effect $(400 \pm 4 \mu \mathrm{g})$ in the combination treatment (Figure 2).

Hepatic proteins level: Our results show that the administration of Zinc causes an increase in the proteins level $(2.04 \pm 0.002 \mathrm{mg})$

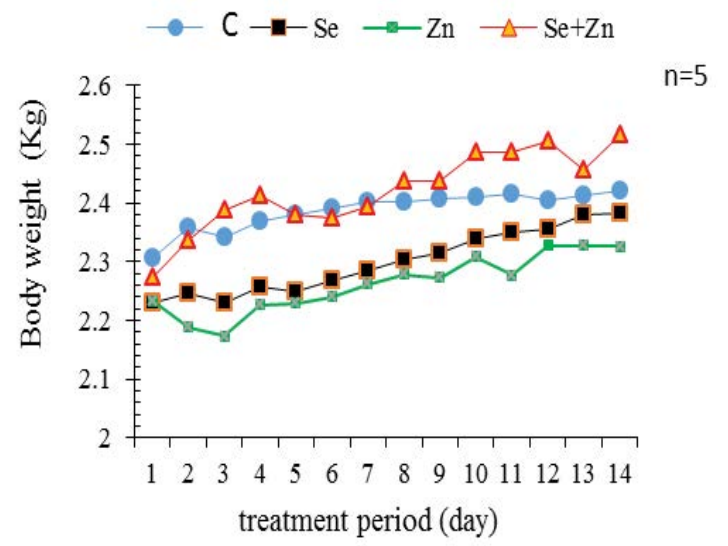

Figure 1: Body weight evolution during the experimental period of rabbits in $\mathrm{Kg}$.

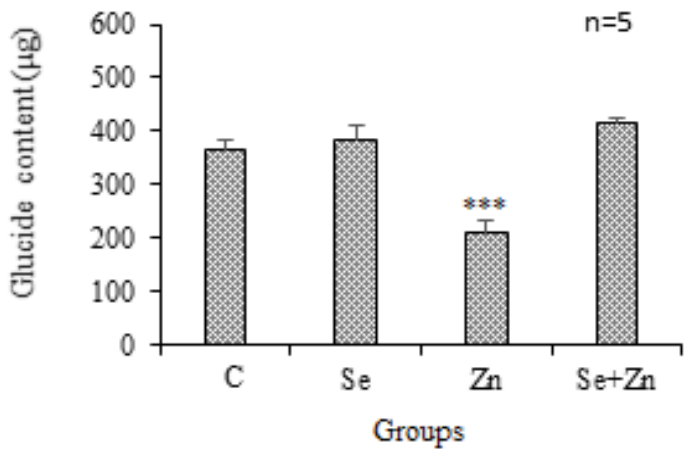

Figure 2: Variations of hepatic glucose level $(\mu \mathrm{g})$ after 14 days of treatment $\left.{ }^{* * *} p<0.001\right)$.

according to the control $(1.65 \pm 0.001 \mathrm{mg})$. Treatment by selenium causes a little increase in the protein level, however, the combination treatment correct the impact of Zinc $(1.97 \pm 0.025 \mathrm{mg})$ (Figure 3).

Lipids level variations: Our results show a high significant $(\mathrm{P}<0.01)$ decrease in hepatic lipid levels after treatment by zinc $(240 \pm$ $10 \mu \mathrm{g})$. This value is corrected by the supplementation of the Se $(310 \pm$ $20 \mu \mathrm{g}$ ). It is to note that selenium has no effect on the fat level (Figure 4).

Assessment of GSH and MDA: Treatment of rabbits with $0.24 \mathrm{mg} /$ $\mathrm{kg} /$ day of the zinc during 14 days, results a highly significant $(\mathrm{P} \leq 0.01)$ decrease of the glutathione content in the liver $(0.055 \pm 0.0001 \mu \mathrm{M} /$ $\mathrm{mg})$ compared to the control group $(0.09 \pm 0.002 \mu \mathrm{M} / \mathrm{mg})$. However, in rabbits treated with the combination $(\mathrm{Zn} / \mathrm{Se})$ a normal level was returned in hepatic glutathione content $(0.085 \pm 0.0015 \mu \mathrm{M} / \mathrm{mg})$ compared with the control group. It is to note that treatment by Se did not affect the level of GSH (Figure 5).

The Figure 6 shows the impact of $\mathrm{Zn}$ and Se on the lipidic peroxidation in hepatocytes by the estimation of the MDA level. Zinc in $0.24 \mathrm{mg} / \mathrm{kg}$ causes a very significant $(\mathrm{p}<.001)$ increase in MDA level $(25.9 \pm 0.9 \mu \mathrm{M} / \mathrm{mg})$ against $(15 \pm 0.5 \mu \mathrm{M} / \mathrm{mg})$ in controls. However, no significant effect was recorded in the groups treated with Se and combination Se/Zn; contrarily it seems that Se correct and protects the lipids peroxidation. 
Citation: Rouabhi R, Gasmi S, Boussekine S, Kebieche M (2015) Hepatic Oxidative Stress Induced by Zinc and Opposite Effect of Selenium in Oryctolagus Cuniculus . J Environ Anal Toxicol 5: 289. doi:10.4172/2161-0525.1000289

Page 3 of 6

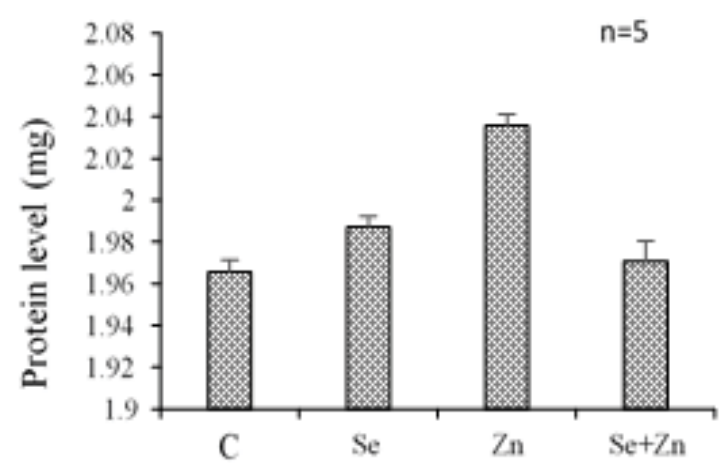

Figure 3: Variations of hepatic proteins $(\mathrm{mg})$ in rabbits after 14 days of treatment.

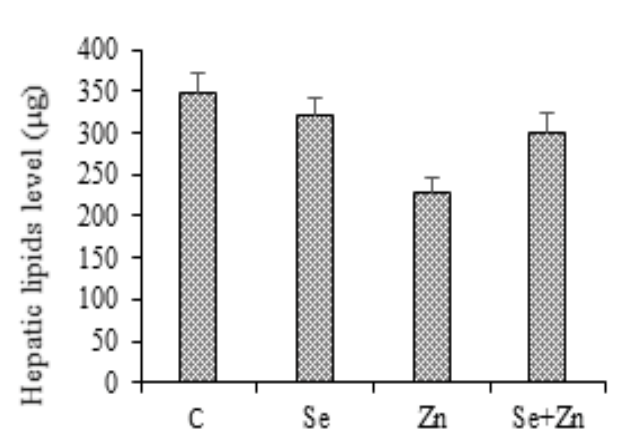

Figure 4: Variations of hepatic lipids level $(\mu \mathrm{g})$ in rabbits after 14 days of treatments $\left({ }^{* *} p<0.01\right)$

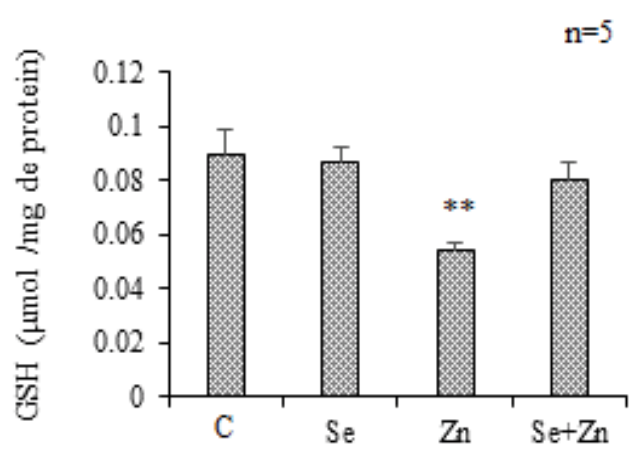

Figure 5: Variation of hepatic GSH ( $\mu \mathrm{M} / \mathrm{mg}$ prot.) in the control and treated rabbits after 14 days of treatment $(p<0.01)$.

Assessment of oxidative stress enzymes: Treatment by $0.24 \mathrm{mg} / \mathrm{kg}$ of $\mathrm{Zn}$ causes a high significant decrease in enzymatic activity of GST, CAT and GPx respectively $(0.0005 \pm 0.00001 \mu \mathrm{M} / \mathrm{min} / \mathrm{mg} ; 0.0003 \pm$ $0.00012 \mu \mathrm{M} / \mathrm{min} / \mathrm{mg}$ and $0.31 \pm 0.02 \mu \mathrm{M} / \mathrm{min} / \mathrm{mg}$ ), according to the group control $(0.00075 \pm 0.00001 \mu \mathrm{M} / \mathrm{min} / \mathrm{mg} ; 0.0028 \pm 0.0002 \mu \mathrm{M} /$ $\mathrm{min} / \mathrm{mg}$ and $0.65 \pm 0.05 \mu \mathrm{M} / \mathrm{min} / \mathrm{mg}$ ), these effects are corrected and ameliorated with the supplementation of Se, (Figures 7, 8 and 9).

\section{Discussion}

In Ecotoxicology, the majority of researches are destined to the investigation of the toxic effects of xenobiotics, while the mechanisms, detoxifying and neutralization agents have not yet taken their value as objective experimental studies. That is why, in this work, we interested as objective, first, to the identification of potential toxicity of zinc on some biochemical and redox statute of rabbits Oryctolagus cuniculus, second, the opposite effect of selenium as an antioxidant agent.

The results of our experiment suggested that the administration of zinc as a stressor, decreases body weight development compared to controls (body weight gain). This was confirmed by the work of [27], they have shown that the administration of zinc reduced the relative liver weight and kidney and decreased body growth in rats.

In contrast, treatment of rabbits by the combination (Zinc/ Selenium) caused an improvement in body weights; this improvement is due to the protective effect of selenium against the adverse effects of Zinc [28-30].

Our results are in agreement with the bibliographic data of $[17,31]$ which showed that the administration of selenium in the rats treated with zinc increased the biliary excretion and reduced hepatic concentrations of zinc, which leads to the reduction of toxic effects of

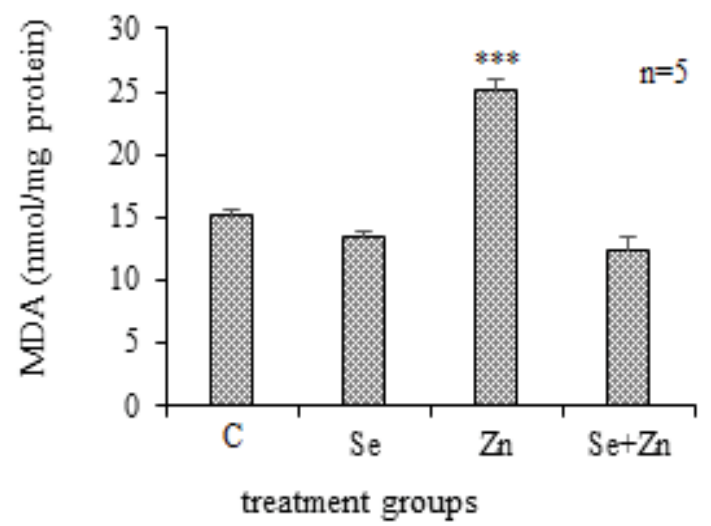

Figure 6: Variation of MDA $(\mu \mathrm{M} / \mathrm{mg})$ level in hepatocytes after 14 days of treatment by $\mathrm{Zn}$, Se and combination $\mathrm{Zn} / \mathrm{Se}(\mathrm{p}<0.001)$.

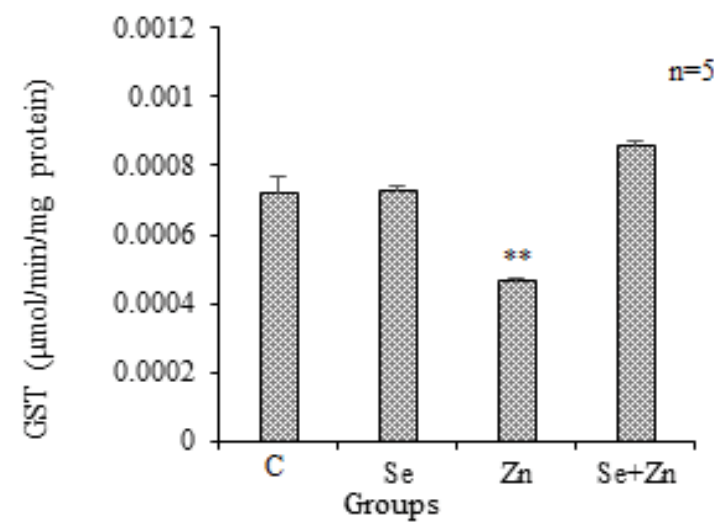

Figure 7: Effect of $\mathrm{Zn}$ and Se treatments on the variation of GST $(\mu \mathrm{M} / \mathrm{mg})$ after 14 days of per os administration $(p<0.01)$. 


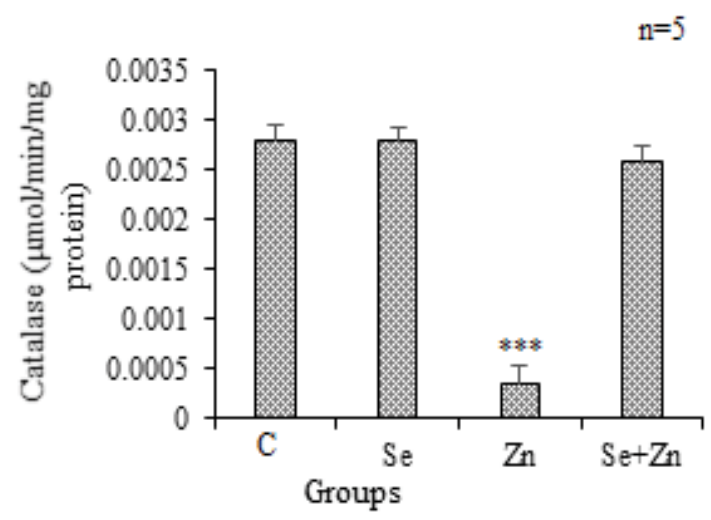

Figure 8: Effect of $\mathrm{Zn}$ and Se treatments on the variation of CAT $(\mu \mathrm{M} / \mathrm{mg})$ after 14 days of per os administration $(p<0.001)$.

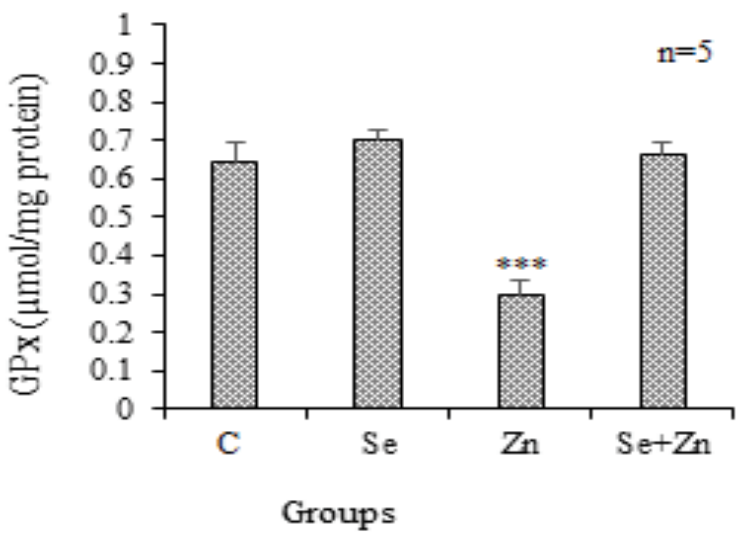

Figure 9: Effect of $\mathrm{Zn}$ and Se treatments on the variation of $\mathrm{GPx}(\mu \mathrm{M} / \mathrm{mg})$ after 14 days of per os administration $(p<0.001)$.

zinc. All of these results show that selenium seems to protect or adverse the toxic effects of Zinc.

The administration of zinc at $0.24 \mathrm{mg} / \mathrm{kg}$ body weight for 14 days in rabbits, resulted many disruptions in the biochemical parameters. Analysis of the results showed an increase in liver proteins in rabbits treated with zinc. We can explain this increase; that the zinc is a trace element but at this dose it increased the synthetic activity of several enzymes and thus stimulated the emergence of stress proteins $[17,32,33]$. Where they can interact with thiol groups $(-\mathrm{SH})$ of the hepatic proteins and reduces the metabolism of these substances, and therefore promotes the storage by the second metabolism pathway [28,31]. This result confirmed the study of over exposure of rabbits to environmental stress (Cadmiun, Copper and Zinc) might alter the metabolism of proteins and amino acids and their synthesis in the liver [17]. Another face, increased hepatic proteins in selenium group explained the beneficial effect (activated synthesis and antioxidant) of selenium in the liver, this explanation confirmed by other data.

The decreased rate of carbohydrate in zinc treated group probably by the use of cellular energy in their operations, by the increased enzymes activity. Both glucagon and zinc stimulated glycogenolysis by increasing the phosphorylation of glycogen phosphorylase but acted oppositely on glycolysis. Zinc overcame the inactivation of pyruvate kinase by glucagon without changing the hormone-induced protein phosphorylation. The antagonistic action of zinc and cAMP on glycolysis together with the rapid and marked decrease in free zinc concentration induced by glucagon (cAMP) may indicate an as yet unknown role of zinc as an important mediator of regulation of carbohydrate metabolism [34].

This result is in concordance with $[35,36]$ results on rats. In contrast, treatment with the combination Selenium/Zinc showed a normal rate of carbohydrate that confirms the protective role of selenium.

Treatment with zinc caused a decreased level of hepatic lipids compared to selenium-treated and controls, this decrease can be explained by the deterioration of liver fat by activation of lipid peroxidation, this pathway stimulated by free radicals where oxidative stress generated by zinc, this is in concord with [37]. Our result was confirmed by the MDA assay results in liver (very highly significant increase) in the group treated with zinc. These results are improved by the addition of selenium to the treatment, which confirm the protective role of selenium.

The Zinc is known for its antioxidant activity. However, in toxic dose, it induces the production of free radicals such as hydrogen peroxide $\left(\mathrm{H}_{2} \mathrm{O}_{2}\right)$, hydroxyl radical $\left(\mathrm{HO}^{-}\right)$, nitric oxide $\left(\mathrm{NO}^{-}\right)$, superoxide anion $\left(\mathrm{O}^{-2}\right)$, and thus changes the balance between the free radicals generated and antioxidant systems, and altering the balance prooxidant/antioxidant and consequently induce oxidative stress [38].

Our study shows that zinc oral gavage at $0.24 \mathrm{mg} / \mathrm{kg} / \mathrm{day}$ for 14 days caused and a significant decrease in GSH levels in liver, our results are in concord with the results of [39]. The decrease of GSH can be explained by several assumptions:

- First, GSH plays a key role in the detoxification of free radicals and heavy metals and in the case of zinc, it directly interacts with high affinity with thiol groups (-SH) of GSH,

- Second, the glutathione can also interact with the free radicals generated by this metalloid.

- Third, Zinc inhibits glutathione synthetase and glutathione reductase, so little GSH occurred. All these factors lead to a sharp decrease of reduced glutathione (GSH) and an increase in oxidized glutathione (GSSG), and consequently a decrease in the activity of GSH-dependent enzymes [17,27].

The organism has an arsenal of enzymes that fight against oxidative stress. However, these enzymes can be affected by zinc, which acts by causing the decrease of the activities of antioxidant enzymes such as CAT, SODs, GPx [17]. Thus, it is necessary to measure the activities of these enzymes to assess the impact of zinc as oxidative stress inducer [27]. GPx is a key antioxidant enzyme, which regulates the level of ROS, (GPx is capable of not only reducing the hydrogen peroxide in water, but also the resulting hydroperoxides of oxidation of unsaturated fatty acids). Thus, protects the cells against damage generated by the toxic dose of zinc, and according to our results there is a decrease in GPx activity in the liver of rabbits treated with Zinc. This decrease is mainly due to an overproduction of hydrogen peroxide and depletion of selenium and GSH in detoxification zinc [40]. Which causes a decrease of enzymatic activity of GPx (GPx requires glutathione and selenium to function properly).

Concerning the glutathione S-transferase (GST), this enzyme plays an important role in detoxification of xenobiotics and/or in the protection against harmful metabolites generated after degradation of 
macromolecules due to their exposure to oxidative stress [41]. Based on our findings, we observed an increase in the GST in the liver. So, GST is involved in the detoxification and elimination of these metabolites and zinc. The effect of zinc on the GSH and the activities of antioxidant enzymes is accompanied by an increase in the amount of free radicals like the hydroxyl radical which in turn can initiate lipid peroxidation [29], and as shown by our results, a very highly significant increase in the rate of malondialdehyde (MDA), which is a biomarker of lipid peroxidation [27]. Our results confirm those of [42], who found impaired antioxidant status in rats treated with zinc. This alteration is accompanied by increased lipid peroxidation and decreased hepatic GSH.

Increased rate of hepatic lipid peroxidation (MDA), the depletion of GSH, increase free radicals and decrease the enzymatic activity of GPx, these are important factors responsible for tissue damage. Catalase (CAT) is the second step in the enzymatic defense system. It supports the hydrogen peroxide produced previously by the SODs and metabolizes into water $[27,30]$.

In liver cells, a zinc decrease the activities of catalase (CAT) this result suggests that the zinc indirectly induces an increase in $\mathrm{H}_{2} \mathrm{O}_{2}$; therefore, it caused a case of oxidative stress. Moreover, supplementation of selenium resulted in substantial improvement, where the rate of glutathione, MDA, the enzymatic activities of GPx, GST and CAT levels in the liver almost back to normal. This is due to the antioxidant effect of selenium, which is a cofactor of many antioxidant enzymes such as glutathione peroxidase GPx, the thioredoxin reductase, wherein the activity of these enzymes is very dependent on the intake of selenium $[17,30,40,43]$.

Our results confirm those of [44] carried out on mice exposed to oxidative stress generated by the ozone $\mathrm{O}_{3}$, which showed that supplementation of selenium may reduce the imbalance pro-oxidant/ antioxidant, by increasing the rate of reduced glutathione and GPx.

Moreover, Zinc and Selenium are metalloids haves similar chemical properties, but different biological effects Selenium is able to interact directly with the Zinc, providing some protection against other toxic metal toxicity such as cadmium [45-47].

In conclusion, this is in vivo experiments to demonstrate that the zinc has an oxidative stress on hepatocytes in spite of its role as essential element, and the protective role of selenium as an antioxidant agent in a very small dose $0.05 \mu \mathrm{g} / \mathrm{kg}$. However, further studies are needed to elucidate the exact mechanism of selenium interaction and more investigation on some other antioxidants with zinc and other micro and macro elements [48].

\section{References}

1. Aoun $H$, Merghadi $H$ (2013) Effet des vitamines $E$ et $D$ sur l'hématotoxicité avec le cadmium chez les lapins. Mémoire Master. Université de Tebessa. Algérie.

2. Lavoie M (2010) Toxiques les métaux? Les modèles écotoxicologiques aident à y voir plus clair. INRS Capsule no. 9: 1-10.

3. Black MR, Medeiros DM, Brunett E, Welke R (1988) Zinc supplements and serum lipids in young adult white males. Am J Clin Nutr 47: 970-975.

4. Chandra RK (1984) Excessive intake of zinc impairs immune responses. JAMA 252: $1443-1446$.

5. Chobanian SJ (1981) Accidental ingestion of liquid zinc chloride: local and systemic effects. Ann Emerg Med 10: 91-93.

6. Hooper PL, Visconti L, Garry PJ, Johnson GE (1980) Zinc lowers high-density lipoprotein-cholesterol levels. JAMA 244: 1960-1961.

7. Murphy JV (1970) Intoxication following ingestion of elemental zinc. JAMA 212:
2119-2120.

8. Allen JI, Perri RT, McClain CJ, Kay NE (1983) Alterations in human natural killer cell activity and monocyte cytotoxicity induced by zinc deficiency. J Lab Clin Med 102: 577-589.

9. Aughey E, Grant L, Furman BL, Dryden WF (1977) The effects of oral zinc supplementation in the mouse. J Comp Pathol 87: 1-14.

10. Drinker KR, Thompson PK, Marsh M (1927b) An investigation of the effect upon rats of long continued ingestion of zinc compounds, with a special reference to the relation of zinc excretion to zinc intake. Am J Physiol 80: 284-306.

11. Katya-Katya M, Ensminger A, Mèjean L, Debry G (1984) The effect of zinc supplementation on plasma cholesterol levels. Nutr Res 4: 633-638.

12. Klevay LM (1973) Hypercholesterolemia in rats produced by an increase in the ratio of zinc to copper ingested. Am J Clin Nutr 26: 1060-1068.

13. Maita K, Hirano M, Mitsumori K, Takahashi K, Shirasu Y (1981) Subacute toxicity studies with zinc sulfate in mice and rats. J Pest Sci 6: 327-336.

14. Straube EF, Schuster NH, Sinclair AJ (1980) Zinc toxicity in the ferret. J Comp Pathol 90: 355-361.

15. Mytilineou C, Kramer BC, Yabut JA (2002) Glutathione depletion and oxidative stress. Parkinsonism Relat Disord 8: 385-387.

16. Uttara B, Singh AV, Zamboni P, Mahajan RT (2009) Oxidative stress and neurodegenerative diseases: a review of upstream and downstream antioxidant therapeutic options. Curr Neuropharmacol 7: 65-74.

17. Harabawy ASA, Mosleh YI (2014) The role of vitamins A, C, E and selenium as antioxidants against genotoxicity and cytotoxicity of cadmium, copper, lead and zinc on erythrocytes of Nile tilapia, Oreochromis niloticus. Ecotoxicol Environ Saf 10: 28-35

18. Dubois M, Gilles KA, Hamilton JK, Rebers PA, Smith F (1956) Colorimetric Method for Determination of Sugars and Related Substances. Analytical Chemistry 28: 350-356.

19. Goldsworthy GJ, Mordue W, Guthkelch J (1972) Studies on insect adipokinetic hormones. Gen Comp Endocrinol 18: 545-551.

20. Shibko S, Koivistoven P, Tratnyek CA, Newhall AR, Friedman L (1967) A method for sequential quantitative separation and determination of protein, RNA, DNA lipid and glycogen from a single liver homogenate or from subcellular fraction. Annal Biochem 19: 415-528.

21. Bradford MM (1976) A rapid and sensitive method for the quantitation of microgram quantities of protein utilizing the principle of protein-dye binding. Anal Biochem 72: 248-254

22. Weckbecker G, Cory JG (1988) Ribonucleotide reductase activity and growth of glutathione-depleted mouse leukemia L1210 cells in vitro. Cancer Lett 40: 257-264.

23. Flohé L, Günzler WA (1984) Assays of glutathione peroxidase. Methods Enzymol 105: 114-121.

24. Cakmak I, Horst WJ (1991) Effect of aluminum on lipid peroxidation, superoxide dismutase, catalase, and peroxidase activities in root tips of soybean (Glycine max). Physiol Plantarum 83: 463-468.

25. Habig WH, Pabst MJ, Jakoby WB (1974) Glutathione S-transferases. The first enzymatic step in mercapturic acid formation. J Biol Chem 249: 7130-7139.

26. Esterbauer H, Gebicki J, Puhl H, Jürgens G (1992) The role of lipid peroxidation and antioxidants in oxidative modification of LDL. Free Radic Biol Med 13: 341 390.

27. Flora SJ, Behari JR, Ashquin M, Tandon SK (1982) Time-dependent protective effect of selenium against cadmium-induced nephrotoxicity and hepatotoxicity. Chem Biol Interact 42: 345-351

28. Jang Y, Lim Y, Kim K (2014) Saccharomyces cerevisiae Strain Improvement Using Selection, Mutation, and Adaptation for the Resistance to LignocelluloseDerived Fermentation Inhibitor for Ethanol Production. J Microbiol Biotechnol 24: 667-674.

29. Machado VS, Oikonomou G, Lima SF, Bicalho MLS, Kacar C, et al. (2014) The effect of injectable trace minerals (selenium, copper, zinc, and manganese) on peripheral blood leukocyte activity and serum superoxide dismutase activity of lactating Holstein cows. Vet J 200: 299-304. 
Citation: Rouabhi R, Gasmi S, Boussekine S, Kebieche M (2015) Hepatic Oxidative Stress Induced by Zinc and Opposite Effect of Selenium in Oryctolagus Cuniculus . J Environ Anal Toxicol 5: 289. doi:10.4172/2161-0525.1000289

Page 6 of 6

30. AL-Rasheed NM, Attia HA, Mohamed RA, Al-Rasheed NM, Al-Amin M (2013) Preventive Effects of Selenium Yeas, Chromium Picolinate, Zinc Sulfate and their Combination on Oxidative Stress, Inflammation, Impaired Angiogenesis and Thermogenesis in Myocardial Infarction in Rats. J Pharm Sci 16: 848-867.

31. Faye B, Saleh S, Konuspayeva G, Musaad A, Bengoumi M, et al. (2014) Comparative effect of organic and inorganic selenium supplementation on selenium status in camel. Journal of King Saud University-Science. 26: 149-159.

32. Saleh R, Mónica B, Javier R, Daniel M, Maria J, et al. (2014) Selenium levels in early weaning diets for gilthead sea bream larvae. Aquaculture 426-427: 256-263.

33. Roussel AM, Favier IH (2009) Essential elements in human nutrition-trace chromium, selenium, zinc and iron. Endocrinology-Nutrition 6: 1-16.

34. Brand IA, Kleineke J (1996) Intracellular zinc movement and its effect on the carbohydrate metabolism of isolated rat hepatocytes. J Biol Chem 271: 19411949.

35. Rana SV, Agrawal VP, Bhardway NG (1981) The effect of dietary cadmium and zinc on lipids, proteins and carbohydrates in rats. Arh Hig Rada Toksikol 32: $157-161$.

36. Aly HF, Mantawy MM (2012) Comparative effects of zinc, selenium and vitamin $\mathrm{E}$ or their combination on carbohydrate metabolizing enzymes and oxidative stress in streptozotocin induced-diabetic rats. Eur Rev Med Pharmacol Sci 16: 66-78.

37. Shah DR, Singh PP, Gupta RC, Bhandari TK (1988) Effect of oral zinc sulphate on serum lipids and lipoproteins in human subjects. Indian J Physiol Pharmacol 32: $47-50$

38. Siscar R, Koenig S, Torreblanca A, Solé M (2014) The role of metallothionein and selenium in metal detoxification in the liver of deep-sea fish from the NW Mediterranean Sea. Sci Total Environ 466-467: 898-905.

39. Demangeon N (2013) lode, sélénium et antioxydants chez le cheval d'endurance, Thèse Pour le doctorat vétérinaire, la faculté de médecine de Créteil, Vosges.

40. Josiane A, Nathalie A, Roussel AM, Sandrine B, Daniel R, et al. (2007) Relationships between selenium, lipids, iron status and hormonal therapy in women of the SU.VI.M.AX cohort. Journal of Trace Elements in Medicine and Biology 21: 66-69.

41. Messarah M, Klibet F, Boumendjel A, Abdennour C, Bouzerna N, et al. (2012) Hepatoprotective role and antioxidant capacity of selenium on arsenic-induced liver injury in rats. Exp Toxicol Pathol 64: 167-174.

42. Soudani N, Ben Amara I, Sefi M, Boudawara T, Zeghal N (2011) Effects of selenium on chromium (VI)-induced hepatotoxicity in adult rats. Exp Toxicol Pathol 63: 541-548.

43. Banji D, Banji OJ, Reddy M, Annamalai AR (2013) Impact of zinc, selenium and lycopene on capsaicin induced mutagenicity and oxidative damage in mice. $J$ Trace Elem Med Biol 27: 230-235.

44. Dolezych B, Elzbieta S (2003) Selenium modifies glutathione peroxidase activity and glutathione concentration in mice exposed to ozone-provoked oxidative stress. J Trace Elem Med Biol 17: 133-137.

45. Ueda F, Nagata M, Nagata T, Shimazaki Y (1988) Effects of zinc and EDTA on tissue cadmium in various smooth muscles in rabbit and guinea-pig. Gen Pharmacol 19: 661-664.

46. Yamaguchi M, Uchiyama M (1987) Preventive effect of zinc for toxic actions of germanium and selenium on bone metabolism in weanling rats. Res Exp Med (Berl) 187: 395-400.

47. Türk S, Mändar R, Mahlapuu R, Viitak A, Punab M, et al. (2014) Male infertility: decreased levels of selenium, zinc and antioxidants. J Trace Elem Med Biol 28: 179-185.

48. Poulsen HE, Prieme H, Loft S (1998) Role of oxidative DNA damage in cancer initiation and promotion. Eur J Cancer Prev 7: 9-16. 